\title{
Singer'ın Mutlak Yoksulluğun Çözümüne Yaklaşımında Sorumluluk ve Haklar Sorunu
}

\author{
NUREVŞAN MARŞ ${ }^{1}$
}

${ }^{1}$ MA, Kastamonu University, Department of Philosophy (Orcid ID: 0000-0003-0489-7874)

\section{Özet}

Bu çalışmada mutlak yoksulluk ve gıdaya erişim sorununa karşı geliştirilen felsefi yaklaşımların başında gelen Peter Singer'ın çözüm önerisi ele alınmaktadır. Singer'ın açlığı ve mutlak yoksulluğu önlemek için öne sürdüğü ahlaki ödev ve bu ödevden doğan sorumluluklarımızın hak temelli bir anlayışla bağdaşıp bağdaşamayacağı tartışımıştır. Bir yandan, Singer kimsenin mutlak yoksulluktan ölmemesi gerektiğini savunmaktadır; bir bakıma, açlıktan ve yoksulluktan ölmenin o insanların yaşam hakkının elinden alınması anlamına geldiğini işaret eder. Diğer yandan, açlık ve yoksulluk sorununu temel haklara erişim sorunu olarak ele almamaktadır. Singer'ın temel insan haklarını göz ardı ettiği katiyen söylenemez ancak tok olanların açlara yardım etmesiyle sorunun çözüleceğini düşünmesi; gıdaya erişimin ve sağlıkı yaşam koşullarının yaşam hakkı kapsamında bir hak olarak talep edilmemesi ve mutlak yoksulluktan mustarip olanların mutlak zenginlerin inayetine terk edilmesini ima edebilir. Buradan yola çıkarak, bu çalışmada Singer'ın mutlak yoksulluk sorununu, temel bir hak olan gıdaya erişim hakkı ve yaşam hakkı bağlamında ele almaması onun sorumluluk anlayışııı bir eksikliği olarak değerlendirilmektedir.

Anahtar Kelimeler: Peter Singer, mutlak yoksulluk, sorumluluk, yardım, gıdaya erişim hakkı 


\title{
Problem of Responsibility and Rights in Singer's Approach to the Solution of Absolute Poverty
}

\begin{abstract}
In this study, Peter Singer's solution proposal, which is one of the philosophical approaches developed against the problem of absolute poverty and access to food, is discussed. The question of whether our responsibilities arising from the moral duty that Singer posits in order to prevent hunger and absolute poverty will be compatible with a rights-based understanding. On the one hand, Singer argues that no one should die of absolute poverty; in a way, he insinuates that dying from hunger and poverty means taking away the right to life of those people. On the other hand, he does not address the problem of hunger and poverty as a problem of access to fundamental rights. It cannot be said that Singer ignored basic human rights. However, he thinks that the problem of starvation will be eased by helping. Proposing this, he implies that access to food and healthy living conditions should not be demanded as a human right but those who suffer from absolute poverty are abandoned to the wealthy's grace. From this point of view, in this study, the fact that Singer does not address the question of absolute poverty as a violation of both the right to food and the right to life is considered to be a lack of his understanding of responsibility.
\end{abstract}

Keywords: Peter Singer, absolute poverty, responsibility, aids, right to food

\begin{tabular}{ll}
\hline Corresponding Author / Sorumlu Yazar & NUREVŞAN MARŞ \\
& LLM, Kastamonu University, Department of Philosophy \\
E-mail / E-posta & nurevsan914@gmail.com
\end{tabular}

Manuscript Received / Gönderim Tarihi

Revised Manuscript Accepted / Kabul Tarihi

To Cite This Article / Kaynak Göster
Sep 24, 2021/ 24 Eylül 2021

Dec 09, 2021 / 09 Aralık 2021

Marş, N. (2021). Singer'ın Mutlak Yoksulluğun

Çözümüne Yaklaşımında Sorumluluk ve Haklar Sorunu,

ViraVerita E-Journal: Interdisciplinary Encounters, Vol.

$14,39-54$. 


\section{Singer'ın Mutlak Yoksulluğun Çözümüne Yaklaşımında Sorumluluk ve Haklar Sorunu}

\section{Giriş: Singer'ın Yoksulluğa Bakışından Doğan Ahlaki Ödev}

Faydacı bir düşünür olan Peter Singer'a göre, insanlar için faydaları önceliklidir ve bu doğal bir durumdur. Fakat etik, bu kabulü, doğal olanı aşmalıdır (Singer, 1972, s. 230). Klasik faydacı düşünürler, doğal olanın 'iyi' olduğunu ve bu nedenle doğal olanı tercih etmemiz gerektiğini savunurlar. Ancak Singer, doğal sözcüğünün iki anlamının birbirine karıştırılmaması gerektiğini ifade eder: Bir anlamıyla insanların yaptığı hiçbir şey doğa-üstü olamayacağından, her şey doğaldır; diğer anlamıyla, insan doğaya sürekli müdahale etmiştir ve müdahalelerin bazıları da olumludur (Singer, 2015, s. 24). Nasıl hastalıkları tedavi etmek doğal olana olumlu bir tür müdahaleyse, etik de doğal veya toplumsal acılara olumlu bir müdahaledir. Bilindiği üzere, faydacı kurama göre, insanlar kendi faydalarına doğal olarak öncelik verirler; fakat başkalarının faydaları da insanı dolaylı olarak mutlu eder; çünkü genelin refahı mutluluğu artırır. Ahlaki kişinin kendi faydasını aşıp, başkalarının faydasını, mutluluğunu-faydacıların ifadesiylegenelin refahını artırmaya odaklanmalıdır. Ahlak, "ben" perspektifini aşamazsa, toplumsal sorunlara başkalarını da ikna eden çözümler bulamaz. Bu nedenle Singer, “Ben'i aşan başkalarının sorunlarına odaklanan bir ahlak anlayışı oluşturmaya odaklanır" (Singer, 2015, s. 34). Ancak bunu yaparken, kendilerini toplumsal veya küresel sorunların dışında gören insanları da ikna etmenin yollarını arar (Kibar, 2010, s. 253).

Singer'ın çözüm aradığı sorunların başında açlık ve aşırı yoksulluk sorunu gelmektedir. Dünyada açlıktan ölen insanların olduğunu bilmek, kimseyi mutlu edemez ya da kimse bunun olması gereken bir şey olduğunu iddia edemez, o zaman bunun için kolları sıvamalıyız der Singer (Singer, 1972, s. 231). Singer, dünyanın yoksul coğrafyalarında sürüp giden kötülüğe ahlaki olarak tepki vermek gerekliliğini, bir ön kabul olarak ortaya koyar; hatta bu kabulü sorgulayanların Singer'ın çalışmasının devamını okumasının gerekmediğini de belirtir (Singer, 1972, s. 231). Kötü koşullarda açlıktan ve hastalıktan ölen insanlar olduğunu bilmek onların bu durumuna çözüm getirme ve yardım etme sorumluluğunu da beraberinde getirir (Singer, 2015, s. 300).

En genel kapsamıyla küresel bir sorun olarak gözümüzün önünde duran açlığa, tedavisi mümkün olan ama yoksulluktan dolayı tedavi edilemeyen hastalıklardan meydana gelen ölümlere çare bulmalıyız. İnsanların en temel gereksinimlerini bile karşılayamadıkları yoksulluk 
koşullarında, Singer bir çözüm bulmanın aciliyetini vurgular: Temel intiyaçlarını karşılamaktan yoksun bırakılan yani mutlak yoksulluğa mahkûm edilen insanlar için bir şeyler yapmalıyız. Singer bu noktada yardım etme yükümlülüğü savını ortaya koyar (Singer, 2015, s. 291). Mutlak yoksulluğun yanı sıra Singer mutlak zenginliğin de tanımını yapmaktadır. Ihtiyaçlarımızı karşılamaya yetecek paradan ve kaynaktan daha fazlasına sahipsek daha açık bir ifadeyle lüks tüketim dışında kendi zevklerimizi karşılayabilecek, kendimizin ve çocuklarımızın geleceğini maddi bakımdan güvence almaya yetecek kadar maddi kaynakları elimizde bulunduruyorsakbu artı-kaynak, mutlak yoksulluk çeken birisini, içerisinde bulunduğu kötü koşullardan kurtarabilir. Çok kötü bir şeyin meydana gelmesini, benzer ahlaki öneme sahip herhangi bir şeyi feda etmeden önlemek eğer elimizdeyse, bunu yapmamız gerekir çünkü aşırı yoksulluk öldürür, der Singer (Singer, 2015, s. 292).

Singer mutlak zenginliğe sahip, yani yiyecek içecek konusunda seçim yapabilen, lüks harcamalar yapabilen, buna rağmen hala ekonomik gücü olan bireylerin ahlaki ödevlerinin olduğunu söyler. Bu ahlaki ödev yardım etme potansiyeli taşıyan bireylerin servetlerinden fedakârlık bile denilemeyecek kadar küçük bir para aktarımıdır. Şöyle örneklendirir Singer: Günde iki kahve içen insan bunun yerine bir kahve içebilir ve o içilmeyen kahvenin ücreti kadar küçük bir meblağ ihtiyaç sahibi insanlara aktarılabilir. Bir kahve eksik içen birey bir fedakârlık yapmış bile sayılmaz; hayatından ve servetinden bir şey eksiltmiş olmaz. İkinci bir örnek; I-pod yerine müzik dinleyebileceğimiz daha ucuz bir alet alabiliriz (Singer, 2015, s. 293). Kısacası Singer, insanların lüks harcamalarını gereksiz ve insafsız bulur. Gelir dağılımını dengelemek, özellikle küresel düzeyde ve kısa vadede pek mümkün görünmemektedir (Singer, 1972, s. 238). Ama açlıkla mücadele çok acil çözülmesi gereken bir sorundur. Bu nedenle, tüm bireyler ellerinden geleni yapmalıdır.

Ahlak, tüm insanlara bazı pozitif ödevler yükler. Bu ödevlerin başında da, yoksulluğu, açlığı elimizden geldiğince engellemek vardır. Singer ve muhtemelen hiçbir kimse bir insanın engellenebilir sebeplerden ölmesinin olumlu bir şey olduğunu söyleyemez. Bunu söyleyemeyeceğimize göre, bu sorunun çözümü için bir şeyler yapmalıyız; aksi adaletli, eşit veya ahlaki değildir. Bir tarafta aşırı lüks tüketen bireyler varken bir tarafın aşırı yoksulluktan hayatlarını tehdit eden koşullar altında yaşaması bireylerin ahlaki ödevlerini yerine getirmediğinin göstergesidir. Bu yüzden potansiyelimiz, gelirimiz veya kaynağımız varsa ödevimizi yerine getirmek zorundayız (Singer, 1972, s. 231-4; 2015, s. 302, 317). 
Singer yardım edebilecekken yardım etme sorumluluğundan ahlaki ödevi aşağıdaki mantıksal çıkarıma dayandırır:

Illk öncül: Eğer kötü olanı, benzer ahlaki öneme sahip hiçbir şeyi feda etmeden önleyebiliyorsak, önlememiz gerekir.

İkinci öncül: Aşırı yoksulluk kötüdür.

Üçüncü öncül: Benzer ahlaki öneme sahip hiçbir şeyi feda etmeden önleyebileceğimiz bazı aşırı yoksulluklar var.

Sonuç: Bazı aşırı yoksullukları önlememiz gerekir (Singer, 2015, s. 302).

Üçüncü öncül, Singer'ın ahlaki sorumluluk yaklaşımına yöneltilen eleştirilere bir yanıt niteliği taşımaktadır. Örneğin, Susan Wolf, Singer'ın kuramını "ahlaki azizliğe” benzetmektedir. Wolf’a göre herkes aziz olamaz ve olmamalıdır da. Çünkü hayatın çeşitliliğini ve ilerlemeyi bizim iyi hayat ideallerimizin peşinden gitmemiz sağlar: Hepimiz aziz gibi davransaydık, "opera, gurme yemekler, şık giysiler ve profesyonel sporlar" olmazdı (Akt. Singer, 2015, s. 320). Singer, Wolf'a ve Wolf'un baktığı yerden kendisini eleştirenlere yönelik, insanlardan aziz olmasını beklemediğini ve kendi kuramının insanların "kişisel ilişkilerini”, "mutluluklarını", ve "zihinsel sağ ıklarını” feda etmesini gerektirmediğini söyler (Singer, 2015, s. 321).

Singer kişilerin açlığı önlemek üzere yardım etme konusunda, fedakârlık meselesinden başka bazı çekinceleri olabileceğini de kabul eder. Bu endişeleri tek tek ele alır ve kişilerin yardım etme konusunda endişelerini giderir. Illk olarak, bir yardım derneğine bağış yaptığımızda, bu bağışın işe yarayacağından emin olamayabiliriz. Yardım derneklerinin giderlerinin büyük bir kısmı idari gelirlere gitmektedir. Bu nedenle, bu haklı bir endişedir. Ancak Singer, bazı yardım derneklerinin gelirlerinin yüzde yirmisinden fazlasını idari amaçla kullanamayacakları konusunda garanti verdiklerini ifade eder. Diğer bir endişe, bu yardımların yoksul ülkelerin hükümetlerine gittiği ve yoksul halka ulaşmadığı endişesi olabilir (Singer, 1972, s. 240; 2015, s. 303-4). Ancak Singer, bazı yardım kuruluşlarının hükümetle çalışmayıp, doğrudan yoksul insanlarla temasa geçtiklerini aktarır. Bazı web sitelerinde de-bunlardan birisini de Singer kendisi kurmuştur: www.GiveWell.org-yardımların ne kadarının doğrudan hangi sorunun çözümünde kullanıldığını görebileceğimizi söyler (Singer, 2015, s. 316). Başka bir endişe de, yoksul coğrafyalara yardım ettikçe, o coğrafyalardaki plansız nüfus artışını dolaylı olarak destekleyebileceğimiz kaygısıdır. Yoksul bölgelerde, özellikle bebek ve çocuk ölüm oranı yüksek olduğu için doğum oranları da yüksektir. Singer bu kaygıyı anlayışla karşılar. Yardımın sadece yiyecek yardımı olarak anlaşımaması gerektiğini ifade eder. Nüfus planlaması, anne çocuk 
sağlığı, eğitim, doğum kontrol, ilaç ve aşı yardımları da yiyecek yardımı kadar önemlidir (Singer, 2015, s. 309-10, 313). Kişiler yardımlarının hangi sorunun çözümüne yönelik olmasını istiyorlarsa, o derneklerle iş birliği yapmalıdırlar.

Singer'ın yardım etme konusundaki çekincelere verdiği bu yanıtlar ikna edici görünmektedir. Ancak Singer daha temel birkaç sorunu göz ardı etmekte ve tartışmamaktadır. Singer'ın yardım etmeye dayalı pozitif sorumluluk anlayışına yöneltilmiş daha temel ve kapsamlı çeşitli eleştiriler bulunmaktadır. Bu çalışmada Singer'a dört tür eleştiri sunulacaktır. Bunlardan ilki, Singer'ın, sorumluluk anlayışını, sorunun politik bağlamından tamamen kopartarak oluşturmaya çalışmasıdır. Aslında bu eleştiriyi Singer yüzeysel olarak tartışmakta ve Nozick'le girdiği polemikte, sorumluluğun tarihsel olması gerekmediğini iddia etmektedir (Singer, 2015, s. 296-7, 308). Bu çalışmada Singer'a yöneltilen eleştiri, Nozick'in tarihsellik tanımından ve Singer'a karşı çıkışından farklı olarak, tarihselliğin politik zeminden bağımsız olamayacağıdır. İkincisi, ihtiyaçların toplumsal koşullara göre değiştiği gerçeğinden hareketle, mutlak yoksulluğun ve mutlak zenginliğin tanımlanmasının hayli zor olduğu ve zenginliği ve yoksulluğu belirleyen kriterlerin sürekli değiştiğidir. Üçüncüsü, Singer'ın yaklaşımının hak temelli olmadığı ve açlıktan ölmenin yaşam hakkının ihlali olduğunu dillendirmemesidir. Dördüncüsü de üçüncü eleştiriyle bağlantılı olarak, yani yiyeceğe erişimin bir insan hakkı olarak tanımlanmasından hareketle, yiyeceğin bir meta olarak görülmemesi gerektiğidir.

\section{Tarihin Getirdiklerinden Sorumlu Olmayan Sorumluluk}

Illk eleştiriyle başlamak gerekirse, Singer'ın ortaya koyduğu pozitif sorumluluk anlayışı, tarihsel bir sorumluluk değildir. Bu eleştiriyi esasen Singer kendisi de ele almış ve yanıtlamaya çalışmıştır. Nozick'in tarihselci adalet yaklaşımıyla kendisininkini karşılaştırmıştır (Singer, 2015, s. 296-8, 308). Nozick'e göre, yoksul kişilerin veya grupların yoksulluğunun geçmişteki veya bugünkü sorumluları biz değilsek, onları kurtarmak da bizim ödevimiz olamaz (Nozick, 2001, s. 189). Singer'a göre, Locke ve Nozick gibi liberter bir perspektife sahip düşünürler, sorumluluğu negatif hakların ihlal edilmemesine indirgemektedirler (Singer, 2015, s. 296-8). Örneğin; bir kişiyi öldürmek kişinin yaşam hakkını elinden almaktır ve temel hakların ihlalidir. Bu durumda öldüren kişi sorumludur. Ancak birilerinin hayatı tehlikedeyse ve ortada bir hak ihlali yoksa onları kurtarmak kimsenin sorumluluğunda değildir (Singer, 2015, s. 298-9).

Singer için öldürmenin sorumluluğu ile yardım edilmezse öleceğini bildiğiniz birisine yardım etmemenin sorumluluğu aynıdır. Eğer bir yerlerde insanların öldüğünü biliyorsak 
bundan sorumluyuzdur (Singer, 2015, s. 300). Singer suçludan ve olumsuzlukları yaratan koşullardan tamamen bağımsız olarak sorumluluklarımızı ortaya koyar. Singer'ın sorumluluk kavramı kendisinin verdiği bir örnekle daha açık hale gelebilir: Bir suya düşmüş, boğulmak olmak üzere olan küçük bir çocuğu, takım elbisenizin ve ayakkabılarınızın mahvolması pahasına kurtarır mıydınız? Hemen suya atlamazsanız, bunun o çocuğu ölüme terk etmek olduğu ve sonucu itibariyle cinayetten bir farkı olmayacağı açıktır (Singer, 2015, s. 300-1).

Singer önünüzde boğulmakta olan çocuk ile Afrika'da açlıktan ölen çocuk ve ülkenize gelmiş bir göçmen arasında çok da fark olmadığını ileri sürer (Singer, 1972, s. 231-2). Dünyanın dört bir yanındaki kurtarabileceğimiz insanları şu an yaptığımızdan daha çok önemsemeliyiz. Böyle yapmazsak, yaşayabilecek olan bir çocuk şüphesiz genç yaşta ölecektir. Bu bir tahmin değildir; bunun doğru olduğunu biliyoruz. Yoksullukla ilgili nedenlerden dolayı her yıl binlerce çocuğun öldüğünü biliyoruz. Bu iki olay arasında fark olmadığından ilk olay için yaptığımız yardım etme eylemini ve sorumluluğu dünyanın farklı bölgelerinde yoksulluktan ölen çocuklar için de hissetmeliyiz. Bu, bizim ahlaki ödevimizdir ve sorumluluğumuzdadır.

Görüldüğü üzere Singer, bireylerin yardım etme sorumluluğunu haklar söylemiyle değil, ahlaki ödevle temellendirmektedir. Kimseye zarar vermemek, örneğin bir kimseyi öldürmemek ahlaki ödevimizdir. Benzer şekilde zarar gören veya ölmek üzere olan birisini kurtarabiliyorsak, kurtarmak da ahlaki ödevimizdir. Singer’a göre birisini öldürmek ve birisinin ölümüne seyirci kalmak sonuçları bakımından eşdeğer sayılabilir ve aynı derecede ağır sorumluluk getirir. Birisini doğrudan öldürmekle, yardım edebilecekken ölümüne seyirci kalmak arasındaki çizgi sanıldığı kadar kalın değildir (Singer, 2015, s. 296-8, 300-1).

Singer'ın bu örnekler üzerinden Nozick'e verdiği yanıt ikna edicidir. Faydacı bir düşünür olan Singer, sorumluluğun nedenleri üzerinde durmamaktadır. Onun için sonuçlarla nasıl başa çıkacağımız, nedenlerin aydınlatılmasından daha önemlidir. Nozick'in tarihselci yetkilendirme kuramından yola çıkarak, dünyadaki mutlak yoksulluktan kendilerini tarihsel olarak sorumlu görmeyenler, bu yoksulluğu hafifletme veya ortadan kaldırma sorumluluğunu da kendilerine ait bir ödev olarak görmeyeceklerdir. Oysa Singer'ın ileri sürdüğü faydacı-sonuççu ahlak temelli görüş, sorumluluğu, bu yoksulluğu hafifletebilecek herkese yükler.

Singer'ın tarihsel sorumluluğu göz ardı ettiği ve hatta hiç önemsemediği eleştirisini, Nozick'in durduğu liberter konumdan değil, daha Marksist bir yerden de sunabiliriz. Marksizm, yoksulluk sorununun sınıflı toplumların, artı ürüne ve artı-değere el koymakla yaratıldığı ve adaletin kaynakların ve ürünlerin daha adil bir şekilde dağıtılmasıyla sağlanamayacağını; emek 
sömürüsüne dayanan sınıflı toplumların ve kapitalist üretim biçimin ortadan kalkması gerektiğini savunur. Böylelikle tarihsel sorumluluk, başlangıçtaki sorumluluk olarak anlaşılmak yerine sorunu yaratan mekanizmalar olarak anlaşılabilir ve bu sayede sorunun çözümüne giden yolu görmüş oluruz. Gerçekten de dünya nüfusunun büyük bir kısmı açlıktan, yoksulluktan, susuzluktan, barınak bulamamaktan, çeşitli hastalıklardan, savaşlardan kayba uğramaktadır. Tarihsel olarak baktığımızda, halkı bu durumda olan devletler, çoğunlukla geçmişin sömürülen, doğal kaynaklarını kullanamayan devletleridir: Bugün bu insanların yoksullukla savaşmalarının sorumluları onları sömüren, haklarını ihlal eden devletlerin politikalarının bir sonucudur. Thomas Pogge'nin sorumluluk ve negatif ödev anlayışı bu olguya dayanmaktadır. Singer'ın kendisi de Pogge'ye bu konuda atıf yaparak kendi görüşünü desteklemiştir (Singer, 2015, s. 297). Pogge zengin devletlerin ve zengin devletlerin vatandaşlarının geçmişte sömürgecilik faaliyetleriyle ve bugün de çokuluslu şirketler aracılığıyla, yoksul coğrafyaların yoksulluğunda payı olduğunu; bu nedenle, negatif ödev yükümlüsü olduklarını iddia eder. Zengin devletler ve zengin devletlerin vatandaşları, negatif ödevleri gereği yoksul bölgelerin insanlarına yardım etmelidirler. Singer, Pogge'ye hak verdiğini belirtirken bile, Pogge'nin bugünün zengin devletlerinin ve geçmişin kolonyalist devletlerinin zarar verme sorumluluğunu ihlal ettiği (s. 635) vurgusundan ziyade, diktatörlerden petrol almayarak onların gücünü zayıflatabileceğimize dikkat çekmektedir (Singer, 2015, s. 297). Kısacası, Singer yine burada bir faydacı olarak nedenler üzerinde değil, sonuçlar üzerinde durmaktadır.

Yoksulluk, günümüzde birtakım makro ve mikro faktörlerin etkisiyle ortaya çıkmaktadır. Makro faktörlerin başında; küreselleşme, küresel sermaye, ekonomik krizler, göç gelmektedir. Eğitimsizlik işsizlik ve bireysel özellikler gibi unsurlar ise mikro faktörler arasında yer almaktadır. Dünyadaki yoksulluğun sorumlularını belirlemeden ve bu sorumluluğu ortaya çıkarmadan küresel yoksullukla mücadele pek mümkün görünmemektedir. Singer’ın da bazılarına dahil olduğu ve destek olduğu pek çok yardım kuruluşu, yoksullukla mücadele yolunda çaba harcamaktadırlar. Ama bir yandan bu kuruluşlar yoksullara yardım etmeye çalışırken, diğer yandan kolonyalist devletlerin doğrudan veya dolaylı olarak dahil olduğu savaşlar yoksulluğu ve başka pek çok sorunu yeniden üretmeye devam etmektedirler. Bu nedenle, sorunu doğru tarif etmek gerekir. Singer 'ın ima ettiği gibi, belki sorunu tarif etmek, sorumluları teşhir etmek, mevcut sorunları çözmez, şu dakika açlıktan ölmekte olan insanları kurtarmaz; ama uzun vadede kalıcı mücadele araçlarını şekillendirmeye yarayabilir. Öte yandan Kibar'ın Singer'ı eleştirilerinde ifade ettiği üzere, bazı sorunların kökeninde kapitalist sistem yatmaktadır: [Singer 
'ın] "yoksulluk konusundaki tavrı bataklığı kurutmak yerine malaryadan, sıtmadan hastalanmış insanları tedavi etmeye çalışmaya benziyor" (Kibar, 2018, s. 202).

\section{Mutlak Yoksulluk, İhtiyaç ve Fedakârlık Kavramlarının Belirsizliği}

Mutlak yoksulluk ve göreli yoksulluk ve tersinden mutlak zenginlik ve göreli zenginlik kavramları Singer'ın yardım etme ödevini gerekçelendirmeye yardımcı olacaktır. Mutlak yoksulluk tanımına göre; bir kimse, "hayatını idame ettirebilmesini daha somut bir ifadeyle, biyolojik olarak var olmaya devam etmesi için gerekli olan donanımı oluşturmasını mümkün kılacak biçimde beslenmesini" karşılayabilecek "ayni ve nakdi gelire sahip değilse", mutlak yoksulluk koşullarında yaşamaktadır (Bilen, Şan ve Aydın, 2005, s. 3-4). Göreli yoksulluk ise, "bireylerin, toplumun ortalama refah düzeyinin belli bir oranının altında olması durumudur" (Ensari, 2010 s. 9). Buna göre, bir kimsenin yoksulluğu kendisinin içerisinde bulunduğu toplumun standartlarının altında bir yaşam sürmesiyle ölçülür. Öte yandan mutlak zenginlik, bir kimsenin ihtiyaçlarını yeterince karşıladıktan sonra bile, lüks harcamaya ve tüketime fazlasıyla kaynağı olması durumudur (Nathanson, 1993, s. 167). Bu tanımlardan yola çıkarak, göreli zenginliğin de bir kimsenin lüks harcamaya veya kendi geleceğini tamamen garanti altına almaya yetecek kaynağı fazla olmasa da toplumsal refah düzeyinin biraz üzerinde yaşamını sürdürmesi olduğu söylenebilir. Örneğin, içerisinde yaşadığımız toplumda, özel otomobili olan bir kimse göreli olarak zengindir ama bu kişi ay sonunda kredi kartı borcunu ödemekte zorlanabilir, dolayısıyla mutlak zengin değildir.

Singer hedeflediği şey, mutlak yoksulluğu azaltarak önlemeye çalışmaktır ve bunu da esas olarak mutlak zenginlikten kaynak devşirerek yapmayı önermektedir: "Bu zengin insanların kendi temel refahlarını tehlikeye sokmadan aşırı yoksullara aktarabilecekleri servetleri vardır" (Singer, 2015, s. 291). Ancak yoksulluk ve zenginlik kişilerin içerisinde bulunduğu tarihsel ve toplumsal koşullara göre değişiklik gösterir. Örneğin, cep telefonu olmayan bir kimse açlıktan ölmeyebilir; ama günümüz dünyasında iş bulmak için bir telefon numarası olması neredeyse zorunludur. Bu nedenle, cep telefonu olmayan bu kişinin aşırı yoksullukla yüzleşme intimali yüksektir. Mutlak veya aşırı yoksulluğu yalnızca yiyecek ekmeği olmaması olarak tanımlamak, günümüz toplumlarında eksiklidir çünkü posta adresi, telefonu, hatta akıllı telefonu ve e-posta adresi olmaması kişinin işsizliğini daimi kılabilir ve kişiyi aşırı yoksulluğa itebilir.

Singer'ın sözünü ettiği şey, aslında hayatta kalmak için asgari koşullara bile sahip olmayanlara bu koşulları sağlamaya ilişkin sorumluluğumuzu hatırlatmaktır. Ancak bireyleri 
pozitif sorumluluklarını yerine getirmeleri için ikna etmekte kullandığı argümanlardan birisi, fedakârlık yapmadan da yardım edebilecekleridir. Öte yandan, Singer’ın fedakârlık olarak görmediği bazı şeyleri, kimileri fedakârlık olarak görebilir. Dolayısıyla, Singer’ın "feda etmeden yardım edebiliriz" argümanı biraz zayıftır. İhtiyaç kavramı, çağdan çağa, toplumdan topluma değişiklik gösterir. Neye ihtiyaç duyulduğunun tanımlanması da epey zordur. Bir zenginin sahip olduğu yat veya lüks araba onun için bir ihtiyaç olarak tanımlanabilir. Ulaşım için daha basit bir araç da işini görecektir, diye itiraz etmemiz bu kişiyi ikna etmeyebilir. Karşılık olarak, koltuk ısıtması olmayan bir otomobilin işini göremeyeceğini söyleyebilir.

Yoksulluk, zenginlik, ihtiyaç kavramlarının belirsizliğinin ötesinde, asıl sorun kimin yardım edecek kimin de yardıma muhtaç konumda olduğunun belirlenmesi ve konumların tahakküm ilişkisi yaratmasıdır. Sosyal adaleti mutlak zenginlerin yardımlarıyla sağlamaya çalışan kuramların bu eşitsizliklerin yeniden üretimine nasıl katkı koydukları bir sonraki bölümde tartışılmaktadır. Daha sonraki bölümde ise, açlığı önleme çabalarının başka sorunlara yol açtığı gösterilmeye çalışılmaktadır.

\section{Yoksulluk Sorununa Temel İnsan Hakları Perspektifinden Bakmak}

Singer'ın yaklaşımı görüldüğü üzere hak temelli değildir: Yiyeceğin ve açlıktan ölmemenin temel bir insan hakkı olduğundan hareketle değil; yoksulluk koşullarında yaşamanın kötü olmasından hareketle küresel adalet kuramını temellendirmektedir. Dolayısıyla, küresel sorunları ele alırken insan hakları perspektifinden bakmamaktadır. Açlıktan ve yoksulluktan ıstırap çekmenin kötü olduğunu söylerken, bu kötülüğe seyirci kalmanın ahlaki kötülük olduğunu ifade eder. İnsanların yiyeceğe veya ilaca ulaşamamaktan ölmesinin yaşam hakkının ihlali olduğundan açıkça söz etmez. Çünkü Singer insan haklarının dayandığı eşitlik düşüncesinin basit bir kabul olduğunu; doğal ve "olgusal temelleri" olmadığını düşünür (Singer, 2015, s. 42). Singer bu konuda haklı olabilir. Insan haklarının ve insanların eşitliğinin doğal temelleri olup olmadığı başka bir çalışmanın konusu olabilir. Burada bu tartışmaya yer verilmesinin sebebi, Singer'ın göz ardı ettiği insan hakları perspektifinin, onun öne sürdüğü "yardım" çözümünden daha sağlam ve kalıcı bir çözüm olabileceğini göstermektir. Uluslararası insan hakları metinlerinin devletler üzerindeki yaptırımı yeterince güçlü olmasa da; bu metinlerde tanınan haklar, kişileri devletler karşısında hukuki ve siyasi olarak güçlü kılmaya yardımcı olur. Ayrıca, insan hakları ihlallerinde, bireylerin uluslararası mahkemelere başvurmasının yolunu açar. Belki de daha önemlisi, bir adalet talebinin hak olup olmadığında toplumsal zihniyetin değişmesine kaynaklık edebilir. 
Insan hakları perspektifi, aşırı yoksulluğun sonuçları olan açlıktan, tedavisi olan hastalıklardan, barınma yetersizliğinden meydana gelen ölümleri, temel hakların ve özellikle de yaşam hakkının ihlali olarak görür. Kuçuradi, barınma sorununu, eğitime erişim sorununu, beslenme sorununu yani sosyal adaletsizlikleri dolaylı olarak bütün temel haklarla ilgili bir sorun olarak tarif etmek gerektiğini öne sürer. Örneğin, bir toplumda bazı çocuklar okula gitmek yerine sokakta çalıştırılıyor ama birileri de "bebek arabalarında köpeklerini gezdiriyorsa", bazıları lüks içerisinde yaşarken, bazıları çöpten ekmek topluyorsa bu ülkede sosyal adaletsizlik egemendir (Kuçuradi, 2011, s. 12). Bu sorunların çoğunlukla ülkelerin veya toplumların ekonomik yoksulluğuyla ilgili olduğu iddia edilir; ama sorun gerçekten yoksulluk olmuş olsa, o toplumda mutlak zenginler, lüks içerisinde yaşayanlar da olamazdı. Kuçuradi'nin ortaya koyduğu gibi yoksul diye nitelendirilen devletlerin sosyal adaleti sağlamaya yönelik bir çabaları olmuş olsaydı, "yokluğu da vatandaşları arasında paylaştırırlardı (Singer, 2015, s. 15). Dolayısıyla sorun, insana verilen değerden, eşitlik ve adalet anlayışının toplumun zeminine yerleştirilmemesinden ve Kuçuradi'nin ifadesiyle, devletin "insan haklarına dayalı" değil de "kendi başına bir varlık" olarak kurgulanmasından kaynaklanır (Kuçuradi, 2011, s. 39). İnsan haklarını amaç haline getirmiş bir devlet, sosyal adaleti sağlamaya çalıştığında, açlığı tamamen bitiremese de, açlıkla mücadeleyi öncelikli hedef olarak belirleyecektir.

Bir kişinin yaşam hakkını elinden almak, o kişinin temel haklarını ihlal etmektir ve bu hakkı alan kişi yani öldüren kişi veya ölüme yol açan sistem sorumludur. Örneğin, kapitalizm toplumsal sınıfları kaldırmak yerine, yoksul ve zengin arasındaki uçurumu yeniden üretmektedir. Üretilen artı-değere el koyan taraf sermayesini artırıp, gücüne güç katarken, diğer yanda hakkı ve emeği sömürülen, yaptığı işe yabancılaşmış bu sömürünün ve haklarının ihlalinin farkında olmayan çoğunluk yer alır. Singer'ın yardımlarla sosyal adaleti sağlama çabası, adaletsizleri çözmek yerine onları yumuşatma çabası olarak görülebilir. Ancak Kerestecioğlu’nun ortaya koyduğu gibi, "iyilik çabası" eşitliğe veya eşitlik yolunda mücadeleye imkân tanımaz:

Aslında bir toplumda adalet ve eşitlik yoksa orada inayet ve iyilik çabası vardır diyebiliriz. Adaletsizlik ve eşitsizliğin, mücadele ve toplumsal dönüşümlerle düzeltilemeyeceği yargısı veya iyilikle yaraları sarma anlayışı ise, kestirmeden ve yüzeysel bir bakış olduğu gibi çoğu zaman toplumdaki köklü düzeltmelerin de önüne geçen bir anlayış olmaktadır (Kerestecioğlu, 2010, s. 228).

Singer temel haklar sorununa eğilmeden sorumluluğu salt ahlaki ödeve indirgemektir; ancak bu sayede Singer'ın bireyci çözümü devreye girebilir ve ahlaki ödev bireylere yüklenir. 
Temel haklar perspektifi de bir bakıma bireycidir. Ama temel hakların sağlanması için insan haklarına dayalı bir devlet ve toplumsal sistem gereklidir. Ayrıca hak temelli yaklaşım, bireylerin yardım etme sorumluluğundan daha eşitlikçidir. Yardım etme meselesinde, yardım eden ve yardıma muhtaç iki taraf vardır ve taraflar birbirlerini bu şekilde kabul ederler. Bu durum zamanla ister istemez bir güç dengesizliğine dönüşür. Tekrar vurgulamak gerekirse, insan hakları perspektifi kişileri başka bireylerin yardımına muhtaç olmaktan korur. Yaşam hakkı kimseye muhtaç olmadan, başkasına bağımlı olmadan yaşamımızı sürdürebileceğimiz kaynaklara sahip olmanın hak olduğunu hatırlatmalıdır. Oysa Singer, bireylerin başka bireylere yardım etmesini öğütlerken, yardıma muhtaç bireyleri yardım eden bireylere bağımlı kılmaktadır. Bourdieu, bu ilişkiyi "yumuşak sömürü" olarak nitelendirir çünkü yardıma muhtaç olan ve yardım gören kişi minnet duymaya başlar ve bu minnet itaate ve boyun eğmeye dönüşür (Akt., Kerestecioğlu, 2010, s. 228). Elbette aynı durum varlıklı bir devletin fakir bir devlete yardım etmesinde de geçerlidir.

Eşit haklar ancak eşitler arasında söz konusu olabilir. Eşitler arasında dayanışma olur. Aksinin koruma ya da inayet olmaması için hak olarak düzenlenmesi gerekir. ... "Korunmaya muhtaç"Iık ancak tüm bunların bileşkesiyle giderilebilir. Yoksa hukuk kimsenin "zavallılığı" üzerine kurulamayacağı gibi, uygulanması gereken "inayet" değil haktır (Kerestecioğlu, 2010, s. 231).

Temel haklar hem dokunulmaması hem de sağlanması gereken haklardır.ii Evrensel İnsan Hakları Bildirgesine taraf olan devletlerin ve uluslararası kuruluşların bu hakları sağlaması ve koruması gerekir. Singer'ın birisini doğrudan öldürmekle dolaylı olarak ölümüne seyirci kalmak arasında sonuçları bakımından pek de bir fark olmadığı iddiası bu noktada haklıdır. Yaşam hakkına saygı duymak ve korumak böyle düşünülmelidir. Kimseyi öldürmemek yetmez; o kişilerin ölümlerine seyirci kalmamak da insan haklarının gereğidir. Bir kimsenin yaşamını sürdürebilmek için gerekli besinlere erişiminin olmaması, bir bakıma o kişinin yaşam hakkının ihlalidir. Devletlerin ve kurumların, o kişinin yaşam hakkına saygı duyması, sonucu değiştirmez ve kişiyi ölüme götürebilir. Dolayısıyla Kuçuradi’nin dediği gibi insan haklarına saygılı olmak yetmez, devletlerin insan haklarına dayalı olması gerekir (Kuçuradi, 2011, s. 41-2).

Hak temelli yaklaşım, özellikle Kuçuradi'nin perspektifinden bakıldığında öncelikle devletlere ödevler yüklüyor gibi görünür. Singer refah ve asgari yaşam şartları bakımından birinci dünya kabul edilen bir ülkede yaşadığı için, kendi ülkesindeki yoksulluktan ziyade dünyanın Afrika ve Güney Asya gibi yoksul coğrafyaları için çözüm üretmeye çalışıyor. Batılı 
(Avustralya'yı da bu kategoriye dâhil edersek) bir ülkede yaşayan yoksul insanla, uzak bir bölgedeki yoksul insanın çıkarları eşittir ancak zaten yakınımızdakine, gözümüzün önünde olana yardım edeceğimizden, Batıdaki kişinin yardıma ulaşması daha kolaydır (Singer, 2015, s. 305-7). Bu noktada, hak temelli yaklaşım "ulusal”, Singer'ın yaklaşımının "küresel” bir çözüm önerdiği söylenebilir. Oysa hak temelli yaklaşım da, insan haklarını koruyacak ve gerektiğinde devletlere müdahale edebilecek küresel bir sistemi gerektirir. Böyle bir küresel sistemin en başta yiyeceğin bir meta olamayacağını ve yiyeceğe ulaşmanın temel bir insan hakkı olduğunu kabul etmesi ve savunması gerekmektedir.

\section{Yiyecek Meta Değil Bir Haktır}

Üçüncü eleştirinin devamı olarak, dördüncü bir eleştiri de Singer'ın yiyeceğin bir hak olduğunu ifade etmemesidir. Günümüz koşullarında, bunca bolluğun ve lüksün olduğu, gıdanın daha ucuza ve daha çok miktarda üretilebildiği, küresel bir sistemde açlıktan ve yoksulluktan ölmek doğal bir neden olarak kabul edilebilir mi? Hayek ve Nozick gibi liberter düşünürler, maddi kaynaklar bakımından eşitsizliğin ve eşitsizliğin sonuçlarının doğal olduğunu düşünmektedirler:

Hayek ve Nozick gibi düşünürler, insanların doğal afetlerle ve kıtlıkla başa çıkma araçlarının günümüzdeki kadar gelişkin olmadığı gibi çağlarda, açlıktan ve kıtlıktan ölümlerin "doğal” olması gibi, mevcut piyasa koşullarının da günümüz doğasını oluşturduğunu ve bu nedenle açlığın ve yoksulluğun belirli bölgeler ve kişiler için “doğal” olduğunu savunurlar (Kibar, 2017, s. 99).

Bu soru Singer'a sorulmuş olsa, muhtemelen doğal olmadığını söylerdi. Liberter düşünürlerle kıyaslandığında, Singer'ın yaklaşımı, özellikle açlıktan ölen insanlar olduğunu bildiğimiz halde bir şeyler yapmıyorsak "ahlaki canavarlar" olduğumuzu ifade etmesi daha insanidir (Parkan, 2007, s. 1). Ama ilk bölümde de tartışıldığı üzere, Singer sonuççu bir düşünür olarak günümüzdeki açlığın nedenlerini ve sorumlularını irdelemez.

Günümüz küresel sisteminde yiyecek bir metadır; alınıp satılır, piyasası ve borsası vardır. Yiyeceklerin, tohumların, ilaçların, aşıların üzerinde mülkiyet hakları, patentler vardır. Yoksul bölgelerdeki insanlar bu patentleri ödeyemediklerinden kendi tohumlarını kendilerini üretemez hale gelmişlerdir. Tarımda kullanılan teknolojinin patentini elinde bulunduran, kendi tarım üreticilerini sübvanse eden, petrol fiyatlarını belirlemekte gücü olan zengin devletler, yiyeceğin ticaretini de kar elde etmeye yönelik olarak yaptıklarından, yoksul devletlerin yiyecek üretimini baltalamaya devam edeceklerdir (Kibar, 2017, s. 103). 
Dünya üzerindeki açlıkla mücadele için kurulmuş Birleşmiş Milletler Tarım ve Gıda Örgütü (FAO), bir yandan yiyeceğin bir hak olduğunu, alınır satılır bir meta olmaması gerektiğini vurgularken, diğer yandan emperyalist devletlerin ve çok uluslu şirketlerin çıkarları doğrultusunda tarım ve gıda politikalarını sürdürür. Hal böyleyken, açlığı bitirme hedefinde pek bir ilerleme kaydedilememektedir (Kibar, 2017, s. 100-1).

Ayrıca bir önceki bölümde tartışılığı gibi, yiyeceğin bir hak olarak değil de bir yardım malzemesi olarak görülmesi, yardım eden ve yardıma muhtaç olan arasında bağımlılık ilişkisini beraberinde getirecektir. İnsanların açlıktan ölmesinin adaletsizlik olduğunu düşünüyorsak, yaşam hakkının kapsamını yiyeceğin de bir hak olduğuna doğru genişletmeliyiz. Bu durumda, bizim sorumluluğumuz yardım etmenin ötesinde, yiyeceğin bir hak olduğunda ısrar etmek olmalıdır.

\section{Sonuç}

Singer'ın tezini tekrar vurgulamak gerekirse, hiç kimse bir insanın açıık, yoksulluk ve tedavisi mümkün hastalıklardan ölmesinin iyi bir şey olduğunu iddia edemez. Buradan hareketle Singer, açlık, yoksulluk ve bu olgulardan meydana gelen ölümlerin tarihsel anlamda sorumlularını aramaz; bugünle ve bugün bunu çözmenin yollarıyla ilgilenir. Singer'ın öne sürdüğü çözüm, bu sorunların ağılığının bireylere yüklediği ahlaki ödevde yatmaktadır. Eğer bir yerlerde insanların öldüğünü biliyorsak bundan sorumluyuzdur. Singer için öldürmenin sorumluluğu ile yardım etmezseniz öleceğini bildiğiniz birisine yardım etmemenin sorumluluğu aynıdır. Bu yüzden o tek bir suçlu bulmaz; o sorumluluklarımızı ortaya koyar. İnsanlar ahlaki sorumluluğunu yerine getirdiğinde dünyada mutlak yoksulluğun kalmayacağını iddia eder. Ayrıca, Singer zenginlere lüks tüketimden vazgeçmeleri halinde bir şey kaybetmeyecekleri ama vazgeçtikleri kaynağı yoksullara aktardıklarında sorunun çözümüne katkı sağlayabileceklerini göstermeye çalışmaktadır.

Bir taraf aşırı beslenip israf ediyor iken diğer tarafın açlıktan ölmesi Singer'a göre ahlaki bir canavarlıktır. Singer’ın bu argümanı, bizlere (en azından tok insanlara) sorumluluğumu hatırlatması ve sorunun çözümü üzerinde düşünmemizi sağlaması bakımından çok değerlidir. Ama Singer 'ın sorumluluğu sadece bireylere yüklemesi ve toplumsal adaletsizlikleri üreten mekanizmaları göz ardı etmesi, onun etiğinin en büyük açmazıdır. Singer faydacı bir düşünür olduğundan, nedenlerden çok sonuçlarla ve kısa sürede sonuç alınabilecek çözümlerle 
ilgileniyor. Elbette kısa vadeli ve daha kolay görünen çözümlerle ilgilenmek son derece doğaldır. Ancak nedenlere inilmediğinde, aynı nedenlerin aynı sonuçları üreteceği de açıktır.

Singer yiyeceğe ulaşmayı temel insan hakları bağlamında ele almaz; açlığı bir hak ihlali olarak değerlendirmez. Ortada olan sorunu çözmek için bireylere, bireysel, bireylerin insiyatifine dayanan çözümler bulur. Halbuki yiyeceğe ulaşmak en temel insan haklarından biridir. Bu sorun insan hakları ihlali bağlamı dışında bir perspektifte değerlendirdiğinde ve bireysel yardımlar çözümün merkezine konulduğunda eşitsizlik ve bağımlılık sürdürülmüş olur. Devletlerin ve uluslararası kurumların yiyeceği bir meta olarak görmeyi bırakması gerekmektedir. Yiyecek üretimi ve yiyeceğe erişim sorunu bireysel yardımların ötesinde yasal ve kurumsal düzenlemelerle çözülebilir.

Açlık ve yoksulluk tarihsel olay ve olgulardan, siyasi politikalardan, ekonomik dalgalanmalar ve hedeflerden bağımsız düşünülemez. Açlığı ve yoksulluğu, toplumsal ve küresel köklerinden soyutlayarak bir çözüm bulunmaya çalışıldığında, sorun temelde durmaya devam edecektir. Eğer insanların açlıktan ölmesinin kötü olduğunu düşünüyorsak, karınlarının doymasının da temel bir insan hakkı olduğunu biliyorsak, insanların hayatta kalmak için en temel ihtiyacı olan yiyeceğin de bir hak olduğunu kabul etmemiz gerekir. Yiyeceğin üretimi üzerindeki uluslararası şirketlerin engellemeleri, baskıları ortadan kalkarsa, yoksul bölgeler yiyeceği kendileri üretebilir hale geleceklerdir ve kimsenin yardımına muhtaç olamadan yaşamalarını sürdürebileceklerdir.

\section{ORCID ID}

NUREVŞAN MARŞ

\section{Declaration of Conflicting Interests}

The author declared that there were no conflicts of interest with respect to the authorship or the publication of this article.
iD https://orcid.org/0000-0003-0489-7874

\section{Çıkar Çatışması Beyanı \\ Yazar bu makalenin yazarlık veya yayımlanmasına ilişkin olarak hiçbir çıkar çatışması olmadığını beyan etmiştir.}

\section{KAYNAKÇA}

Bilen, M., Şan, M. K. \& Aydın, M. K. (2005). Yoksulluk Sorunu Üzerine. Bilgi Sosyal Bilimler Dergisi, (1), 1-26. Erişim adresi: https://dergipark.org.tr/tr/pub/bilgisosyal/issue/29119/311518

Ensari, S. (2010). TÜiK'in Yoksulluk Analizleri Üzerine. Maliye ve Finans Yazıları, 1 (87), 9-15. Erişim adresi: https://dergipark.org.tr/tr/pub/mfy/issue/16293/170825 
Kerestecioğlu, F. (2010). Hak Mı, İnayet Mi? Hak Almak, Hak Vermek, Yardımseverlik ve Kurtarıcılık Üzerine Bir Deneme. Hukuk Felsefesi ve Sosyal Arkivi, (ed. Hayrettin Ökçesiz ve Gülriz Uygur), İstanbul Barosu yay., 227-234.

Kibar, S. (2010). Eşitlik Olmadan Adalet Olur Mu?, Hukuk Felsefesi ve Sosyal Arkivi, (ed. Hayrettin Ökçesiz ve Gülriz Uygur), İstanbul Barosu, 253-261.

Kibar, S. (2017). Böcek Yemenin Nesi Yanlış? ÇAKÜ Sosyal Bilimler Enstitüsü Dergisi, Cilt 8, Sayı:1: 96-113.

Kibar, S. (2017). Dört Bireyci Kuramın Toplumsal Adalet Sorunu Ele Alışlarındaki Temel Varsayımlarının Bir Eleştirisi. Kaygı 28, 1-16.

Kibar, S. (2018). Peter Singer. Modern Felsefe Tartışmaları, (ed. Eray Yağanak). İstanbul: Sosyal Yayınları, 175-203.

Kuçuradi, (2011). İnsan Hakları: Kavramları ve Sorunları. Ankara: Türkiye Felsefe Kurumu.

Nathanson, S. (1993). Patriotism, Morality, and Peace. ABD: Rowman and Littlefield Publishers Inc.

Nozick, R. (2001). Anarchy, State and Utopia. ABD: WileyBlackwell.

Parkan, B. (2007). Önsöz. II: Uygulamalı Etik Kongresi Bildiriler Kitabı. Ankara: Dumat Ofset.

Pogge, T. (2001). Eradicating Systemic Privety: Brief for a Global Resources Dividend. Journal of Human Development, 2 (1), 59-77.

Singer, P. (1972). Famine, Affluence, and Morality. Philosophy and Public Affairs, Vol. 1, No. 3, 229-243.

Singer, P. (2015). Pratik Etik (Üçüncü Basım çev. Nedim Çatlı). İstanbul: İthaki.

\section{Sonnotlar}

\footnotetext{
' Singer ahlak ve etik arasında bir fark gözetmez ve Pratik Etik kitabının ilk bölümünü bu tartışmaya ayırmışır. Kimilerine göre kültürel çağrışımları olan ahlak kavramının bağlayıcı olması için evrensel değerlere ve ilkelere dayanması gerekmektedir. 'Ahlak' Arapça'dan; 'etik' Eski Yunanca'dan dilimize geçmiştir ve eşanlamlı kavramlardır. ii Temel hakların dokunulmaması gereken haklar olduğunu, buna karşın Evrensel İnsan Hakları Bildirgesinde yer alan bazı hakların talep edilen ve kurumlar tarafından sağlanması gereken haklar olduğu ve bu hakların da temel olmadığı bazı düşünürler tarafından savunulmaktadır. Bu makalenin sınırları kapsamında bu tartışmaya girilmeyecektir. Hem dokunulmaması hem de sağlanması gereken hakların temel haklar olduğu ve yaşam hakkı gibi bazı hakların hem dokunulmaması hem de sağlanması gerektiği iddia edilmektedir.
} 